\title{
Domestication and Sustainable Use of Genetic Resources of a Native Tree with High Economic Potential in Ghana
}

\author{
Theresa Peprah', Kwame Antwi Oduro ${ }^{1}$, Daniel E. Kwaku Addo Siaw ${ }^{2}$, \\ Joseph Rexford Cobbinah'1, Zacharia Tchoundjeu ${ }^{3}$, Anthony John Simons ${ }^{4}$, \\ Ramni Jamnadass ${ }^{4}$, Daniel Aninagyei Ofori ${ }^{1}$ \\ ${ }^{1}$ CSIR-Forestry Research Institute of Ghana, Kumasi, Ghana \\ ${ }^{2}$ College of Agriculture and Natural Resources, Faculty of Renewable Natural Resources, Sunyani, Ghana \\ ${ }^{3}$ World Agroforestry Centre (ICRAF), Yaounde, Cameroon \\ ${ }^{4}$ World Agroforestry Centre (ICRAF), Nairobi, Kenya \\ Email: ${ }^{*}$ kwameoduro@gmail.com
}

Received 18 June 2015; accepted 26 September 2015; published 29 September 2015

Copyright (C) 2015 by authors and Scientific Research Publishing Inc.

This work is licensed under the Creative Commons Attribution International License (CC BY). http://creativecommons.org/licenses/by/4.0/

c) (i) 0pen Access

\begin{abstract}
Allanblackia parviflora A. Chev., an underutilized fruit tree species commonly found in tropical rainforest of West Africa, has potential for integration into agroforestry systems for economic and environmental benefits. The seed oil of $A$. parviflora is considered economically important but wild fruits collection produces an average of 40 tons of oil annually. However, over 100,000 tons of Allanblackia seed oil is needed annually by food and cosmetics industries. The need to domesticate and conserve $A$. parviflora to ensure adequate sustainable supply of seed oil and to sustainably manage the genetic resources is therefore critical. This paper reviews the current state-of-the art on domestication and sustainable use efforts of Allanblackia. Propagation methods have been developed to encourage large scale commercial cultivation, include grafting, rooting of stem cuttings and research into improved seed germination. Range-wide germplasm collection has been undertaken leading to establishment of 140 accessions in a gene bank for future source of germplasm. Mother blocks, i.e. established plots consisting of grafts, seedlings and cuttings, have been established at Rural Resource Centres with 58 elite clones, which have been recommended for distribution to farmers. The diversification of cropping systems to include $A$. parviflora trees is projected to contribute to community livelihoods development and poverty reduction through large-scale production and supply chain development of the species. Furthermore, the integration of $A$. parviflora into agroforestry systems is important for the conservation of the genetic resources of the species.
\end{abstract}

${ }^{*}$ Corresponding author.

How to cite this paper: Peprah, T., Oduro, K. A., Siaw, D. E. K. A., Cobbinah, J. R., Tchoundjeu, Z., Simons, A. J., Jamnadass, R., \& Ofori, D. A. (2015). Domestication and Sustainable Use of Genetic Resources of a Native Tree with High Economic Potential in Ghana. Open Journal of Forestry, 5, 678-685. http://dx.doi.org/10.4236/ojf.2015.57060 


\section{Keywords}

\section{Agroforestry, Conservation, Germplasm, Supply Chain, Propagation}

\section{Introduction}

The Allanblackia species, a dioecious multipurpose tree genus of the family Clusiaceae, consists of nine species (van Rompaey, 2003). Species of this genus occur in the humid forest of Africa in West, East and Central African regions extending from Sierra Leone to Tanzania. They have several uses including shade, timber, and medicine, but the economically most important use is the production of edible oil from the seed. On average, over 100,000 tons of Allanblackia seed oil is needed annually by food and cosmetics industries (Kattah, 2010). Due to the commercial value of the oil, the genus Allanblackia is seen as a crop of high potential interest for the development of rural communities (Ofori et al., 2008; Peprah et al., 2009). The seed oil is used traditionally for cooking and soap making in villages and communities where the species occur. The composition of the oil and its relatively high melting point and the fact that it requires less chemical processing than palm oil make the fat a valuable alternative for palm oil in e.g. margarine and cosmetic products (Orwa \& Oyen, 2007; Shrestha \& Akangaamkum, 2007).

Collection of Allanblackia fruits from the wild for extraction of fat from the seed began in Ghana (for $A$. parviflora), Nigeria (for A. floribunda) and Tanzania (for A. stuhlmannii) in 2002. From 2002 to 2008 the supply chain could not meet the demand for Allanblackia oil. It then became evident that harvesting from wild stands was insufficient, but also unsustainable and economically not viable. This led to the conclusion that there was a need to conserve the species, both in situ and ex situ, to ensure that harvesting for oil extraction did not threaten existing populations and that the genetic resources would be available for future use. The need to domesticate, i.e. adapting and cultivating $A$. Parviflora for human use, became evident.

In 2002 a corporate multi-country private-public partnership known as Novella ${ }^{1}$, with strong development, extension and conservation components, was established to drive the domestication programme of Allanblackia (Shrestha \& Akangaamkum, 2008). The possibility of building a sustainable production of a sizeable tonnage of Allanblackia oil per annum, with fair returns to collectors and local processors, was the dream of the Novella partners. All the partners committed themselves to helping conserve natural forest areas where the species occurred and stimulated a small-holder production supply chain. It was particularly agreed that material entering cultivation should be of sufficient genetic quality that could provide an adaptive capacity to potential changes in environment and user requirements.

Allanblackia parviflora, endemic to West Africa (Hawthone \& Gyakari, 2006; Orwa \& Oyen, 2007), is among the Allanblackia spp. being promoted. It is a potential candidate fruit tree species that can be introduced into agroforestry systems due to its narrow crown leading to less competition with crops. Enthusiasm of farmers to collect fruits for extraction of nuts for sale has gained an enormous momentum. However, wild collection has been found to be unsustainable. The maximum quantity of seeds collected from the wild is about 110 tons per annum, which is far below the expected target of 2000 tons/year (Oppong, 2008). In view of this, efforts are being made to increase production of $A$. parviflora species in Ghana through domestication and conservation of the species.

This paper aims to provide information on efforts made towards conservation, domestication and sustainable use of $A$. parviflora in Ghana. Such information is necessary in promoting community livelihoods and poverty reduction through commercial scale production and supply chain development of $A$. parviflora.

\section{Biology and Species Distribution}

\subsection{Botany of A. parviflora}

A. parviflora is considered a multi-purpose tree species with its local name and uses varying according to the region or community in Ghana (Table 1). It is a medium-sized, tree that grows to a height of about $40 \mathrm{~m}$. The bole

\footnotetext{
${ }^{1}$ Novella partnership was formed to bring together stakeholders with different interests and organisational capacities to drive the domestication process.
} 
Table 1. Local names and uses of $A$. parviflora in different regions of Ghana.

\begin{tabular}{|c|c|c|c|c|c|}
\hline Region & Local name & Oil & Medicine & Shade & Timber \\
\hline Brong Ahafo & Sonkyi & + & & + & \\
\hline Eastern & Atrodua & & + & & + \\
\hline Western & $\begin{array}{l}\text { Sonkyi, Osono dokono, } \\
\text { Kusie adwe, kusie aduane, Dufufui, } \\
\text { Akosobolo, Krupi, Bohe }\end{array}$ & + & & + & \\
\hline Ashanti & Sonkyi & + & & & \\
\hline
\end{tabular}

Source: Siaw et al. (2003).

is cylindrical or slightly fluted, rarely greater than $50 \mathrm{~cm}$ dbh with narrow crown of horizontal branches with large leaves, which have shiny surfaces and numerous lateral nerves forked near the margins. The thick bark of A. parviflora, making the species resistant to wild forest fires, is reddish-brown with small rectangular or circular scales over small red pits (Hawthorne, 1990; Hawthorne \& Gyakari, 2006). The species is dioecious (Peprah et al., 2009) and can bear over 250 fruits (Siaw et al., 2003) with an average number of seeds per fruit being about 24 .

\subsection{Distribution, Abundance and Fruiting of A. parviflora}

A. parviflora occurs in the high forest zone from Guinea and Sierra Leone to Ghana. It is most abundant in the wet evergreen forest zone, especially on slopes and away from disturbed areas (Orwa \& Oyen, 2007). In Ghana, national inventories conducted in 1995-1996 and 2001-2002 in areas outside forest reserves (off-reserves) and in forest reserves (on-reserves) respectively did not provide detailed information on the stocking of $A$. parviflora in the high forest zone (MRI, 2002). As a result, the Novella project carried out a stock survey in both off-reserve and on-reserve forest areas in four ecological zones, namely moist semi deciduous north west (MSNW), moist semi deciduous south east (MSSE), wet evergreen (WE) and moist evergreen (ME) (Figure 1). The purpose of the stock survey was to determine the distribution and abundance of A. parviflora in the high forest zone of Ghana; and to provide information for supporting decision-making concerning the sustainable use and management of A. parviflora genetic resources (Siaw et al., 2003).

Siaw et al. (2003) found A. parviflora to occur in all the four ecological zones surveyed (Figure 1). The species was found to be sparsely populated throughout the moist semi deciduous forests (MSNW and MSSE) but more abundantly in the evergreen forests particularly on slopes and away from disturbed areas. The stocking varied across the ecological zones; an average of 2 trees per ha and 1 tree per ha in on-reserves and off-reserves respectively. The WE ecological zone had the highest stocking density of the species in both on-reserves and off-reserves (Siaw et al., 2003).

The percentage of $A$. parviflora trees within on-reserves in the ecological zones observed to be in fruit during the inventory period (September-December) is presented in Figure 2. In the on-reserves, most of the A. parviflora trees in fruit had dbh ranging from $20-60 \mathrm{~cm}$. In total, $15.6 \%$ of the enumerated trees within the forest reserves were found to be in fruits. Within the ecological zone, ME had 17\%, WE had 16\% and MSSE had 3\% of the A. parviflora trees fruiting. MSNW had none of the enumerated A. parviflora trees fruiting. Differences in A. parviflora fruit size and shape were not site specific, but tree-to-tree variation has been reported to be significant (Peprah et al., 2009). In the off-reserves, most of the enumerated trees (86\%) in the MSSE were in fruits. The proportion of fruiting trees in the other ecological zones was quite low ranging from $18 \%, 27 \%$ to $54 \%$ of enumerated trees in MSNW, WE, and ME ecological zones respectively. In all, 33\% of the enumerated A. parviflora trees were found to be in fruits in the off-reserve areas (Siaw et al., 2003).

\section{Achievements in Domestication and Sustainable Use}

\subsection{Supply Chain Development}

Under the Novella project, a sensitization programme was organized within the local communities to encourage farmers to engage in the Allanblackia business by collecting Allanblackia fruits and growing Allanblackia trees. Allanblackia growing communities were divided into zones, and buying centres using the semi-deciduous and 


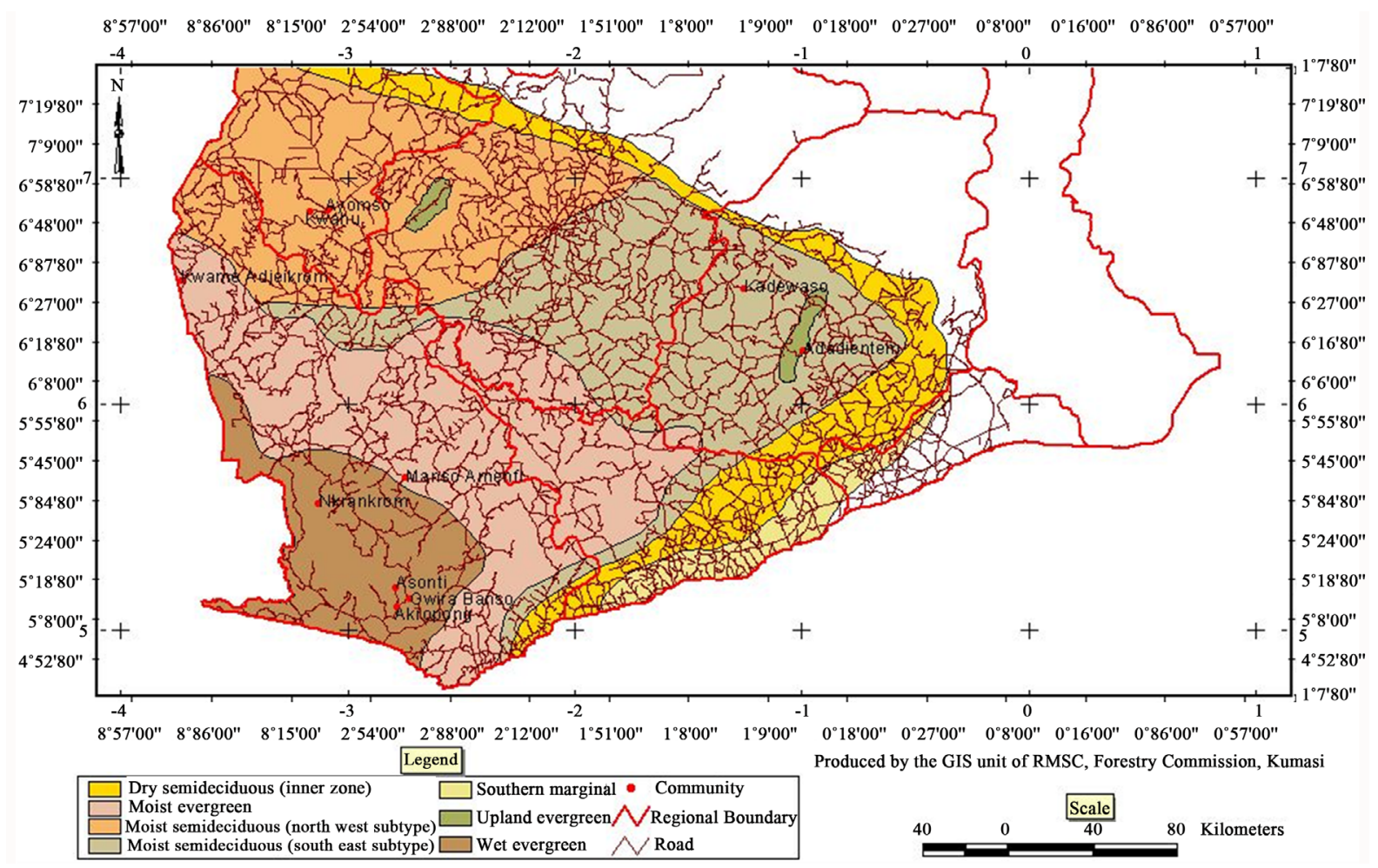

Figure 1. Distribution of A. parviflora in Ghana.

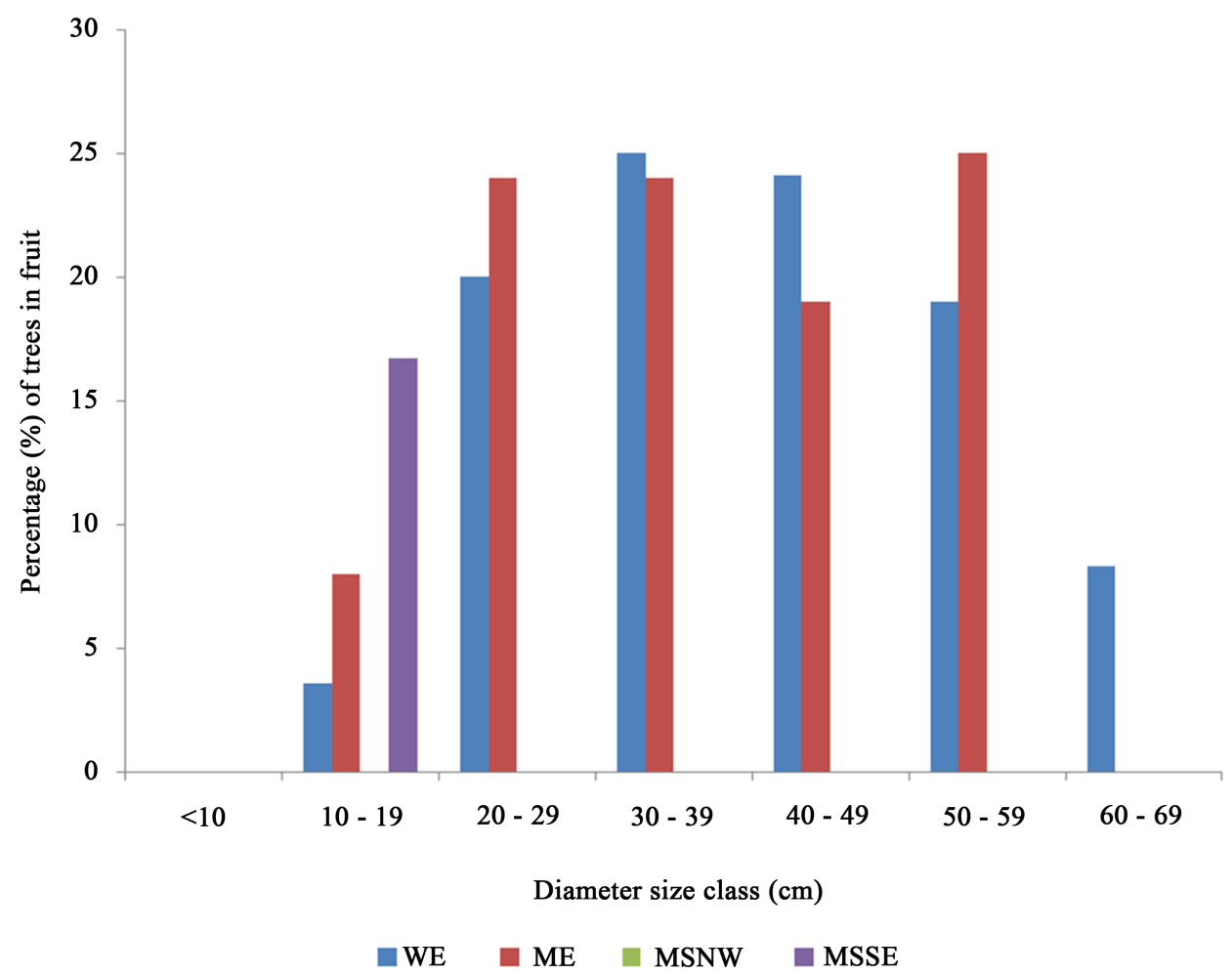

Figure 2. Percentage of $A$. parviflora trees in fruit in dbh size classes in four ecological zones in Ghana. WE (Wet Evergreen), ME (Moist Evergreen), MSSE (Moist Semi-deciduous South East), MSNW (Moist Semi-deciduous North West). Source: Siaw et al. (2003). 
wet evergreen ecological zones as basis. Within each buying centre, the local communities were encouraged to select a focal person who was trained and then entrusted with managing the centre. At each centre, Novel Development Ghana Limited ${ }^{2}$ provides funds for the focal person to purchase the seeds. The Allanblackia seeds are transported to warehouses and then sent to a privately owned crushing mill. The supply chain has been operating since 2004 and the quantity of Allanblackia seeds obtained from wild collection ranges from only 9 tons in 2004 to 110 tons in 2006. The highest quantity of Allanblackia collected was in 2006 (110 tons) and this translates into 40 tons of oil. In total, Tanzania, Ghana and Nigeria produce a mean of about 150, 40 and 20 tons of oil respectively per annum (Kattah, 2010). However the basic minimum quantity to sustain the Allanblackia oil business on the international market is 240 tons of oil per annum highlighting the need for domestication and planting of $A$. parviflora to meet this demand.

\subsection{Genetic Diversity}

Analysis of genetic diversity is very important in any tree domestication programme for identification of superior genotypes and also for proper clonal deployment. Studies on variation in fruits and seed morphology of one hundred and fifty trees growing in different parts of Ghana showed no ecological differences in fruit yield, fruit shape and seed health. Large variations in fruit size and shape were however observed among individual trees sampled (Peprah et al., 2009). The pattern suggests a high potential for genetic improvement through individual selection (Peprah et al., 2009). In the meantime, targeted collection based on fruit size and seed yield is assumed to be a valid approach for selection and has been adopted in sampling. Seedlings and grafts raised from these selected trees are being distributed to farmers for on-farm planting. Then again vegetative propagules (grafts, seedlings and cuttings) from these selected trees are used for the establishment of mother blocks (an established plots consisting of grafts, seedlings and cuttings) for further (vegetative) propagation, and also for the establishment of "gene banks" for conservation purposes (Munjuga et al., 2008).

\subsection{Propagation of A. parviflora}

Under normal nursery conditions, untreated Allanblackia seeds can take more than seven months to start germination. In Ghana, removal of the seed coat and incubating the seeds in polythene bags at a temperature range of $23^{\circ} \mathrm{C}-31^{\circ} \mathrm{C}$ has enhanced seed germination, with seed germination starting from week two and reaching a rate of up to $75 \%$ at 10 months (Ofori et al., 2011). Other constraints associated with fruit production of Allanblackia species are the dioecy nature of the species (which is associated with production of either male or female seedlings) and the long time needed until first flowering.

As an interim measure, vegetative propagation was adopted to produce quality planting materials with known genetic quality, sex and reduced gestation period when ontogenetically matured parts are used. This has been possible by rooting of leafy stem cuttings, grafting and air layering (Anegbeh et al., 2006; Atangana et al., 2006; Atangana \& Khasa, 2008; Ofori et al., 2008). Already, flowering and fruiting have been observed on one to four years old grafts (Ofori et al., 2008; Asaah et al., 2010). Some problems faced with vegetative propagation were that rate of rooting of cuttings is slow and the root system quality is also poor resulting in low number of roots per cutting. Plagiotropism has also been observed on cuttings but this is being addressed by the use of orthotropic shoots.

\subsection{Germplasm Distribution System and Planting}

In order to enhance efficient distribution of planting stocks, a decentralized distribution system was adopted. The strategy was through the establishment of state of the art nurseries within the Allanblackia growing zones to serve as a hub for distribution of planting stocks to farmers. Seven of such nurseries were established in different locations. The criteria for site selection included; suitability of site for Allanblackia cultivation, readiness of the communities to plant Allanblackia, community's acceptance to run and own the facility, easy accessibility as well as the availability of permanent source of water. These nurseries, also known as Rural Resource Centres (RRC'S), served as training and knowledge centres for nursery managers, farmers and extension staff. Further dissemination of planting stocks to remote areas has been through the establishment of satellite nurseries by

\footnotetext{
${ }^{2}$ Novel Development Ghana Limited (NDGL) is registered in Ghana as a company limited by guarantee. NDGL was incorporated in 2006 and is focused on working with rural farmers to improve their livelihoods through establishing a sustainable business in Allanblackia seed supply, tree planting and oil production.
} 
farmers who receive training at the RRCs. Furthermore, NGOs such as Novel Ghana, IUCN, FORM Ghana have been involved in the training of farmers and distribution of seedlings to farmers for planting. In order to facilitate planting of Allanblackia, demonstration plots and mother blocks have been established on-farm, in the RRCs and research Stations. In addition, FORM Ghana is spearheading large scale Allanblackia cultivation in some degraded forest reserves at Oyumso near Agogo in the Ashanti Region of Ghana.

\subsection{Gene Conservation}

Range wide germplasm collection was undertaken from 2005-2008 following a stock survey (Siaw et al., 2003). Seven sites ranging from Wet evergreen to Moist Semi-deciduous forest zones where the species occurs were selected. The target was to identify at least 21 fruiting trees in each site and collect at least 30 fruits from each tree, but these targets were rarely achieved. Each tree encountered was marked and given identification number. Records on each tree such as geographical coordinates (GP 76 Garmin, USA), height, diameter at breast height, estimated number of fruits on each tree were recorded on a passport data sheet. Each tree was visited at least two times in a month for collection of adequate number of fruits that fall on their own. Fruit characteristics (fruit weight, number of seeds, length and breadth of each fruit) were recorded for ten fruits sampled from each tree. This was followed by the estimation of fruit volume for recommendation for selection of high yielding trees for conservation in mother blocks and mass propagation (Peprah et al., 2009). In addition to the conservation of the selected trees, all accessions collected were also conserved in gene banks. Records are being taken on growth, flowering and fruiting and sex ratio. Current information shows that well managed seedlings can fruit within 6 years after field establishment as opposed to 10 - 12 years provided by farmers (Ofori \& Peprah, 2011).

\section{Threats}

The potential market for Allanblackia oil can exceed 100,000 tons/year, whereas the current production level is about 200 tons/year. This current production is only achieved through wild Allanblackia fruit collection in the forests, which is not sufficient to meet the current market demands both in terms of volumes and price. Apart from being economically unsustainable, wild harvesting of Allanblackia fruits is not regarded as ecologically sustainable because 1) it threatens biodiversity hot spots (i.e. areas harbouring huge diversity of wild plant and animal species in their natural habitat) where Allanblackia is found, 2) the number of wild Allanblackia trees is already decreasing by forest destruction, and 3) intensive fruit collection leads to low natural Allanblackia regeneration rates in the forests. To avoid these negative impacts on the environment and to achieve the full opportunities of the Allanblackia project for raising rural livelihoods, it became evident for Allanblackia domestication and significant on-farm planting programmes, in diversified smallholder agroforestry systems, involving millions of Allanblackia trees.

\section{Discussion and Conclusion}

The World Agroforestry Centre (ICRAF), together with a number of international and African regional organizations (NGO's, research institutes, and local and national government institutions) and donors, has been putting their efforts together to bring Allanblackia species under commercial scale production for seed oil, and to promote development, genetic conservation as well as poverty reduction in the African tropical forest belt. Together they have formed a partnership to promote the domestication and supply chain development of seed and seed oil from Allanblackia species, including A. parviflora in Ghana. It was initially quite difficult to convince Ghanaian farmers of the economic potentials of Allanblackia oil since earlier initiatives to cultivate and domesticate other tree species had failed, thereby causing the farmers to lose all their investments made in the initiatives. The limitations of the earlier initiatives included lack of buyers for the fruits and seeds, poor fruiting of tree species resulting from poor site-species matching, and lack of compensation to affected farmers. With $A$. parviflora, the situation has proved different since progress made so far has been very encouraging and farmers have started reaping some direct benefits. The extra cash income obtained from $A$. parviflora seed has helped improve the conservation status of the resource and has also motivated farmers to plant and protect A. parviflora trees on their farms. This has created a large demand for mass production of good quality planting stock for distribution to the farmers.

As part of the Novella project, the extent of the genetic resources of Allanbackia species in the country was assessed. The stocking of $A$. parviflora in Ghana was found to vary among ecological zones, in which the spe- 
cies was found in natural stands in the Western, Central, Ashanti and Eastern Regions of the country, in forest reserves and off-reserve forest areas. The inventory conducted showed an average of 2 trees and 1 tree per hectare of $A$. parviflora occurring in forest reserves and off-reserve forest areas respectively (Siaw et al., 2003). The proportion of trees bearing fruit was much lower than the total number of trees encountered, which might be partly due to the dioecy of the species (Peprah et al., 2009). Currently seeds collected in wild stands and the average quantity of seeds collected per year are approximately 100 tons/year, which is far below the target of 2,000 tons/year (Oppong, 2008).

Judging from the low stocking in natural stands, the quantity of seeds obtained is not enough to meet the demand for Allanblackia seeds. It thus became necessary to domesticate the species and encourage large scale planting of the species. In order to provide enough planting stock, new propagation methods were developed. Progress was made in grafting (Ofori et al., 2008), development of techniques for the rooting of stem cuttings (Anegbeh et al., 2006) and investigation into methods to improve seed germination (Ofori et al., 2011). Research on the propagation by air layering is in progress; the technique is yet to be fine-tuned.

Maintenance of farmers' interest is crucial in efforts to conserve, develop and promote growing of the species. The concept of participatory tree domestication (Tchoundjeu et al., 2006) was adopted where farmers participated in tree selection, fruit collection, propagation and evaluation of productive capacity and quality of planting materials. The germplasm distribution system was decentralised through the establishment of Rural Resource Centres (RRCs) and satellite nurseries. Farmers' associations were formed at the RRCs and farmers underwent training in propagation and field planting.

To ensure the continuous availability of germplasm, range-wide germplasm collections were undertaken for characterization of the species. In July 2007 a genebank was established with 140 accessions at Benso (Moist/ Wet Evergreen Forest Zone, with an average annual rainfall of $>1800 \mathrm{~mm}$ ) to serve as source of reproductive materials. In addition to the genebanks, mother blocks (established plots consisting of grafts, seedlings and cuttings) were established at the RRCs, using 58 elite clones which had been recommended for distribution to farmers. Farmers' motivation to plant A. parviflora was boosted when they realized that grafts and seedlings could fruit within 4 and 6 years respectively, instead of 15 years had been perceived by the farmers. It is anticipated that the diversification of farmers' cropping systems with $A$. parviflora will have positive impacts resulting from enhanced production systems and diversified income structures.

Currently, the most important activity in this programme is the promotion of Allanblackia cultivation and development in sound agroforesty management systems. Current research needs include molecular diversity analysis of selected clones to support the identification and further deployment of the clones. With the current interest to plant $A$. parviflora and conservation by farmers, the species is set to become another "Golden" tree (besides cocoa) for Ghana and Africa in the near future.

\section{Acknowledgements}

We thank Unilever for funding this study. We are also grateful to the staff of CSIR-Forestry Research Institute of Ghana who were involved in Novella project, World Agroforestry Centre and Novel Development-Ghana for their assistance and encouragement. Support provided by our field guides and farmers from whose farms samples were collected is also acknowledged.

\section{References}

Anegbeh, P. O., Tchoundjeu, Z., Simons, A. J., \& Roy-Macauley, H. (2006). Domestication of Allanblackia Floribunda: Vegetative Propagation by Leafy Stem Cuttings in the Niger Delta Region of Nigeria. Acta Agronomica Nigeriana, 7, 1116.

Asaah, E., Tchoundjeu, Z., Ngahane, W., Tsobeng, A., Kouodiekong, L., Jamnadass, R, \& Simons, A. J. (2010). Allanblackia Floribunda: A New Oil Tree Crop for Africa: Amenability to Grafting. New Forests, 41, 389-398. http://dx.doi.org/10.1007/s11056-010-9230-Z

Atangana, A. R., \& Khasa, D. P. (2008). Preliminary Survey of Clonal Variation in Rooting of Allanblackia Floribunda Leafy Stem Cuttings. Canadian Journal of Forest Research, 38, 10-15. http://dx.doi.org/10.1139/X07-151

Atangana, A. R., Tchoundjeu, Z., Asaah, E. K., Simons, A. J., \& Khasa, D. P. (2006). Domestication of Allanblackia Floribunda: Amenability to Vegetative Propagation. Forest Ecology and Management, 237, 246-251.

http://dx.doi.org/10.1016/j.foreco.2006.09.081 
Hawthone, W. D., \& Gyakari, N. (2006). Photoguide for the Forest Trees of Ghana, a Tree Spotters Guide for Identifying the Target Trees (p. 270). Oxford: Oxford Forestry Institute, Department of Plant Sciences.

Hawthorne, W. D. (1990). Ecological Profiles of Ghanaian Forest Trees (345 p). Tropical Forestry Papers No. 29, Oxford: University of Oxford.

Kattah, C. (2010). Developing a Sustainable Allanblackia Business in Africa. Oral Presentation, First Allanblackia Conference, Monrovia, 2-3 February 2010, 15.

MRI (2002). Timber Resources Stand Tables for Production Forest Reserves in the High Forest Zone of Ghana. 2001 Multi Resource Inventory Results. Kumasi: Resource Management Support Centre.

Munjuga, M., Ofori, D., Sawe, C., Asaah, E., Anegbeh, P., Peprah, T., Mpanda, M., Mwaura, L., Mtui, E., Sirito, C., Atangana, A., Henneh, S., Tchoundjeu, Z., Jamnadass, R., \& Simons, A. J. (2008). Allanblackia Propagation Protocol. Nairobi: The World Agroforestry Centre.

Ofori, D. A., \& Peprah, T. (2011). Domestication of Allanblackia parviflora in Ghana (p. 10). Report to ICRAF, January 2010-March 2011.

Ofori, D. A., Peprah, T., Addo-Danso, S. D., Cobbinah, J. R., \& Simons, A. J. (2008). The Potential of Allanblackia parviflora for Wealth Creation. Poster Presented at ICRAF Science Meeting, Nairobi, 3-7 March 2008, 1.

Ofori, D. A., Peprah, T., Cobbinah, J. R., Atchwerebour, H. A., Osabutey, F., Tchoundjeu, Z., Simons, A. J., \& Jamnadass, R. (2011). Germination Requirements of Allanblackia parviflora Seeds and Early Growth of Seedlings. New Forests, 41, 337-348. http://dx.doi.org/10.1007/s11056-011-9252-1

Ofori, D. A., Peprah, T., Henneh, S., Von Berg, J. B., Tchoundjeu, Z., Jamnadass, R., \& Simons, A. J. (2008). Utility of Grafting in Tree Domestication Programme with Special Reference to Allanblackia parviflora A. Chev. Ghana Journal of Forestry, $23 \& 24,42-48$

Oppong, K. (2008). Allanblackia Seed Oil Supply Chain Management in Ghana. Allanblackia Stakeholders' Workshop, Cape Coast, 30 July 2008, 8.

Orwa, C., \& Oyen, L. P. A. (2007). Allanblackia parviflora A. Chev. In H.A.M. van der Vossen, \& G.S. Mkamilo (Eds.), Vegetable Oils; Plant Reseources of Tropical Africa (vol. 14, pp. 28-30). Wageningen: PROTA Foundation.

Peprah, T., Ofori, D. A., Siaw, D. E. K. A., Addo-Danso, S. D., Cobbinah, J. R., Simons, A. J., \& Jamnadass, R. (2009). Reproductive Biology and Characterization of Allanblackia parviflora A. Chev. in Ghana. Genetic Resources and Crop Evolution, 56, 1037-1044. http://dx.doi.org/10.1007/s10722-009-9475-6

Peprah, T., Ofori, D. A., Siaw, D. E. K. A., Oduro, K. A., Cobbinah, J. R., Tchoundjeu, Z., Jamnadass, R., \& Simons, A. J. (2009). Conservation and Use of Genetic Resources of Allanblackia parviflora A.Chev. in Ghana. Paper Presented at a Regional Workshop on Local Fruit Tree Species for Nutrition, Poverty Alleviation and Biodiversity Conservation in SubSaharan Africa, Ouagadougou, 23-26 February 2009, 9.

Shrestha, R. B., \& Akangaamkum, A. D. (2007). Novella Partnership: A Partnership for Poverty Reduction through Sustainable Enterprise Development Based on Allanblackia 2002-2007 (p. 20).

Shrestha, R. B., \& Akangaamkum, A. D. (2008). Novella Partnership: A Partnership for Poverty Reduction through Sustainable Enterprise Development Based on Allanblackia, SNV Ghana (p. 20).

Siaw, D. E. K. A., Cobbinah, J. R., Kankam, B. O., Derkyi, S. A., Oduro, K. A., Agyili, J., \& Peprah, T. (2003). Final Report on Allanblackia Floribunda; Novella Project (69 p). Submitted to Unilever Ghana Ltd. by Forestry Research Institute of Ghana.

Tchoundjeu, Z., Asaah, E. K., Anegbeh, P., Degrande, A., Mbile, P., Facheux, C., Tsobeng, A., Atangana, A. R., Ngo-Mpeck, M. L., \& Simons, A. J. (2006). Putting Participatory Domestication into Practice in West and Central Africa. Forests, Trees and Livelihoods, 16, 53-69. http://dx.doi.org/10.1080/14728028.2006.9752545

van Rompaey, R. (2003). Distribution and Ecology of Allanblackia spp. (Clusiaceae) in African Rain Forests, with Special Attention to the Development of a Wild Picking System of the Fruits. ECOSYN Consulting, Vlaardingen: Wageningen and Unilever Research Laboratories. 